\title{
Effect of the Type of Ownership in the Financial Performance: The Case of Firms in Latin America
}

\author{
José Satsumi López-Morales ${ }^{1}$ \& José G. Vargas-Hernández ${ }^{2}$ \\ ${ }^{1}$ Economic-Administrative Sciences Department, Instituto Tecnológico de Veracruz, México \\ ${ }^{2}$ Centro Universitario de Ciencias Económico Administrativas (CUCEA), Universidad de Guadalajara, México \\ Correspondence: José Satsumi López-Morales, M.A. de Quevedo 2339, Col. Formando Hogar, Veracruz, \\ Veracruz, México. E-mail: jsatsumi@gmail.com
}

Received: July 28, 2014

Accepted: August 8, 2014

Online Published: September 25, 2014

doi:10.5539/ibr.v7n10p125

URL: http://dx.doi.org/10.5539/ibr.v7n10p125

\begin{abstract}
The aim of this paper is test if the type of ownership (Foreign Private, Local Private and State) affects the financial performance of firms in Latin America in the period from 2005 to 2011. In order to reach this aim, a sample of 29 firms that operates in different countries from Latin America was selected (mainly from Brazil, Mexico, Chile, Argentina and Colombia). Likewise in order to measure the type of ownership, the firms of the sample were categorized in three kinds of ownership such as: foreign private, local private and state ownership. Likewise the Return on Equity (ROE) was used to measure the financial performance. Finally in order to reach the main aim of this paper, we test the hypothesis using a regression analysis with SPSS. The results shed that the type of ownership is not relevant to the financial performance in Latin American context.
\end{abstract}

Keywords: financial performance, Latin American firms, type of ownership

\section{Introduction}

Nowadays the firms around the world face new challenges. The relevance that has taken the international markets have made that the firms have had to develop new internal and external capabilities. In addition, the environment has played an important role too, for example the political and economic reforms carried out during the 90's in some developing countries have impacted in different ways the development and strategies of the firms.

Inside these political and economic reforms are the selling of state-owned firms to private agents, this is known as privatization (Yarrow, 1986). However, even though the privatizations were a common practice during the 90's (Rodrik, 2006), the governments currently have maintained the ownership of some firms mainly from strategic sectors as: oil, mining and energy (Cuervo-Cazurra, Inkpen, Mussachio \& Ramaswamy, 2014). The main aim of these firms is support to the local governments to fulfill social goals instead of pursuit the searching of financial benefits (Knutsen, Rygh \& Hveem, 2011).

In the case of Latin America the trend has not been different. Many governments held the ownership of important firms as: Petrobras in Brasil, Pemex in Mexico, Ecopetrol in Colombia and so on. This issue has generated that the "state firms" increase their power in order to maintain the control of internal market and compete abroad.

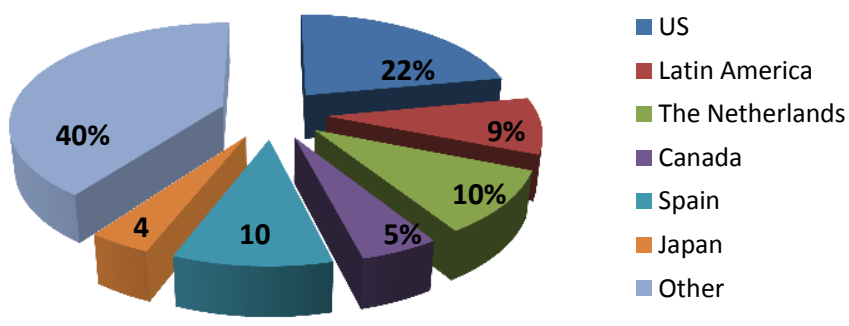

Figure 1. Latin America and the Caribbean: origin of foreign direct investment, 2007-2011

Source: ECLAC, 2012. 

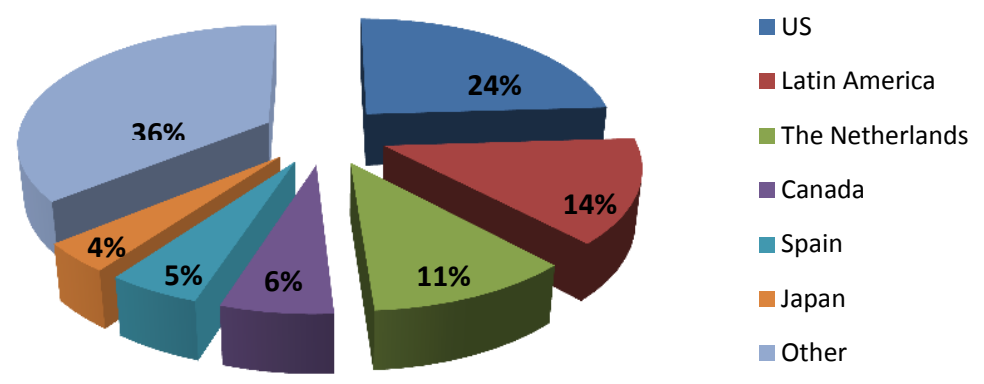

Figure 2. Latin America and the Caribbean: Origin of foreign direct investment, 2012

Source: ECLAC, 2012.

In addition, according with Figures 1 and Figure 2 the commercial openness has prompted to the firms from developed countries to carry out important investments in different Latin America countries. According with ECLAC (2012) the flows of Foreign Direct Investment (FDI) from developed countries toward Latin America have had an important impact in the last years. Around the 50\% of the FDI that have received Latin America had its origins from USA, The Netherlands, Canada, Spain and Japan. In addition to the privatized firms some firms have maintain their private origins. Hence some of these firms not only have been important in the internal markets, but also have been major players worldwide in some sectors. For example: Cemex from Mexico, Techint from Argentine and Vale from Brazil. These firms have competed against the big firms from developed countries.

Therefore the purpose of this paper is to address the effect of the type of ownership in the financial performance of firms that operates in Latin American countries. In the literature is accepted that the private firms reach a better financial performance that the state firms (Megginson \& Netter, 2001). Hence was selected a sample of firms with different types of ownership in order to test the hypothesis of this paper.

\section{Theoretical Background}

\subsection{Type of Ownership}

The type of ownership is an important topic in corporate governance literature. In this regard several studies about the type of ownership have been carried out the last years (Cuervo-Cazurra, 2014; Inkpen, Mussachio \& Arocena \& Oliveros, 2012; Le \& Chizema, 2011; Eskil \& Goldeng, 2008). These studies have increased the literature about the influence of the type of ownership in the firms. Moreover these studies have focused in two main topics: first in compare the private firms and the state firms (Reeves \& Ryan, 1998; Dewenter \& Malatesta, 2001) and second compare the performance of the firms before and after a process of privatization (D'souza \& Megginson, 1999). In both cases the studies presents inconclusive results due to the differences of goals of the firms studied (Bozec, Breton \& Cote, 2002).

Likewise these studies have not paid attention in the relationship between the type of ownership and financial performance specifically in emerging regions as Latin America. Nevertheless the type of ownership has begun an important issue in this region since during the last 20 years due to the change of ownership (mainly state to private ownership), in Latin America has been a common practice as from 90's. In this regard a great number of state firms were sold to private agents (Rodrik, 2006). In addition most of the studies related to the type of ownership have been conducted in developed economies.

On the other hand there are evidences that indicate significant increases in the financial performance of companies that changed their type of ownership (Djankov \& Murrell, 2002; Megginson \& Netter, 2001; Wright, Buck, T. \& Filatotchev, 2002). These empirical findings suggest that the performance of the firms have different behaviors regardless of their type of ownership.

Peng, Tan \& Tong (2004) have identified five types of ownership:

1). State firms ownership, these firms have the characteristic that are large and complex, and generally suffer a lack of resources. These companies have in the States their main source of financing, supplier and distributor. 
2). Private firms are the opposite of state firms. These companies are generally owned by family groups, have few resources to research and development $(\mathrm{R} \& \mathrm{D})$, but they are very market-oriented.

$3)$. Collectively owned firms, state-owned but operate as private. The organizational model is a hybrid between state-owned and public companies. For example, they have close relationships with governments and are market driven.

4). Foreign investment enterprises (FIEs), are a category that includes strategic alliances and subsidiaries of multinational companies (MNC's). This typology does not necessarily include the public owned firms, which are very important in the context of this research.

5). Public owned firms are those that are listed in the stock exchange and capture shareholders from private investors and have some rights related to ownership, governance and decision making of firms. It is important to notice that the public owned companies are different that the state-owned enterprises in terms of ownership, governance and decision making.

The above classification shows that in addition of the more common types of ownership (state firms and private firms), and in some cases given to the various environmental and internal changes that companies have faced in the last 20 years, have emerged new types of ownership. This fact has generated a difficulty in order to categorize firms according to their type of ownership. Therefore it is important to note that within the two main types of ownership (public and private) exist subdivisions.

\subsection{Financial Performance}

Firms have to be careful in the development of strategies, selection of targets, monitoring the results and the impact of these factors on their performance. These facts are why the interest in the study about the firm performance has increased in the last 20 years (Taticchi, Balachandran \& Tonelli, 2012), resulting in a large body of academic literature about this topic. Generally the primary goal of firms is to reach an adequate performance that makes them increase their profits. However, the literature on the subject provides evidence that there is not an appropriate measure of performance of a firm (González-Benito \& Suarez-González, 2010; Vij, Harpreet \& Bedi, 2012). The result is an extended number of indicators of different types of firm performance.

Performance is measured for the results of the firm. The results are often measured by the goals previously established. These make possible evaluate the progress of the firm's objectives. The above approach is associated with financial performance (Barnes \& Hinton, 2012; Kariv, Menzies, Brenner \& Fillion, 2009). It has been mentioned characteristics, advantages and limitations of performance. The key question is what performance means? The definition of performance is not an easy task (Barnes \& Hinton, 2012; Kariv et al, 2009; Schiuma \& Marr, 2003). The term can be used at various levels of the company, for example, individual performance, team performance and organizational performance (Brudan, 2010). Hence, there is complexity for defining it correctly.

The definitions of performance are diverse. Sandvik and Sandvik (2003) define it as goal levels achieved by the firm. Moreover, the performance can be oriented toward future results, appropriate to the needs of each company and based on a causal model of inputs and outputs results (Lebas, 1995). Performance is a term in which each person is placing the concepts that best fit to their interests and to the same environment (Barnes \& Hinton, 2011). Neely, Adams \& Kennerley (2002) conceptualize performance measurement as the process of quantifying the efficiency and effectiveness of past action. The above definition states that the performance is a tool that helps managers in choosing courses of action.

With the above, for the purpose of this research, the definition of performance measures made by Neely et al. (2002) will be used as a basis of the definition of firm performance. Since the data to which there is access are historical data of the company, this is also the best to fit the objectives of this research. Likewise in this study measure the financial performance with Return on Equity (ROE). It is an accounting-based measure of performance that is commonly used in international business literature (Hitt, Hoskinsson \& Kim, 1997; Harr, 1989; Grant, 1987; Vernon, 1971). ROE focuses on the relative efficiency with which the resources available have been utilized by a firm to earn profit on behalf of its shareholders (Contractor, Kumar \& Kundu, 2007).

Furthermore an additional reason for using this measure is that is easily available. In addition it is a measure of financial performance in the short term (Thomas \& Eden, 2004). Likewise an important limitation of ROE is that only capture the profitability of the last year. Finally ROE is an indicator that contributes to understand the financial successful or unsuccessful of the firm, in this regard contribute to reach the main objective of this paper. 


\section{Hypothesis}

During the 90's of the last century, several governments in Latin America carried out the implementation of trade liberalization policies (Cuervo-Cazurra \& Dau, 2009). These reforms were proposed by the "Washington Consensus," which consisted of 10 recommendations about public policy (Correa, 2002; Rodrik, 2006). These recommendations were proposed by the International Monetary Fund, World Bank and the U.S. government (called "Washington institutions").

Within these recommendations were privatization of firms, which is the act of selling state-owned enterprises to private (Cuervo-Cazurra, Inkpen, Mussachio \& Ramaswamy, 2014; Megginson, Nash \& Van Randenborgh, 1994). These processes were very common practices in different Latin American countries during the 90's. The governments sold large firms to private investors, such as: Imevision in Mexico (now TVAzteca), Embraer in Brazil and Ypf in Argentina. Moreover some companies continued their private origin from the early 90's to the present $t$, for example, Cemex and Bimbo (Cuervo- Cazurra, 2010). Besides, other companies despite the opportunity in those days remained still state-owned as the big oil firms: Pemex and Pdvsa. (Casanova, 2010). Many of them, regardless of their ownership structure are called "multilatinas".

In addition, from trade liberalization in the 90's, Latin America has been an important region where MNCs from developed countries like U.S.A., Japan and Europe have carried out important investments. These investments are why since several years ago have begun to notice the important role of companies like Sony, Samsung, Shell, among others. This has generated significant business competition for Latin American firms. This suggests that some firms in Latin America have had significant financial performance. The reforms implemented in the 90's have influenced the type of ownership and these in turn may generated a better financial performance for local private, state companies and foreign private companies operating in Latin American countries.

In regard of these assumptions the next hypothesis was developed:

H1: The type of ownership (If the firm is foreign private, local private and state ownership) is related with the financial performance in the firms that operate in Latin America.

\section{Research Design}

\subsection{Source and Sample Data}

The hypothesis is tested of using data of the ranking "Las 500 mayores empresas de America Latina" for the period 2005-2011. The ranking is the most important data source of firms from Latin America (Lopez-Morales, Wise-Lozano \& Vargas-Hernandez, 2014; Cuervo- Cazurra, 2010).The information of this ranking is collected for the Chilean magazine "America Economia". This ranking is elaborated since the 80's. Besides Latin America is an ideal laboratory to test this kind of assumption (Dau, 2011) because many Latin America governments have implemented different policies that has affected the firms'ownership. Additionally the study of Latin America firms is an important gap in the literature (Chang, 2011; Thomas \& Eden, 2004).

The sampling was done by convenience, 29 firms that operate in Latin America were included. The selection was made due to that can be obtained the complete data of this number of firms in the period of study (2005-2011). It is important to point out that the number of firms selected (29) and the period of study (2005-2011) were selected due to the possibility to collect complete data for the statistical procedure using SPSS.

\subsection{Variables and Analytic Method}

It is included one measure for each variable. For the independent variable "Type of Ownership" (TPROP), it was designed a scale where classified the firms in accordance with their specific "type of ownership". First, it was assigned the number 1 to the firms that are "foreign private". These firms are the subsidiaries of firms that are not from Latin America origin (e.g. General Motor from USA, Arcelor Mittal from India). Second, it was assigned the number 2 to the firms that are "local private", these firms are origins from Latin America countries and are owned by private agents de (E.g. Cemex from Mexico, Vale from Brazil and so on). Finally, it was assigned the number 3 to the firms that are "local state". These firms have their origins from Latin America countries and are owned by the state (e.g. Pemex from Mexico, Pdvsa from Venezuela.

In addition for the dependent variable "financial performance" it is selected the Return on Equity (ROE) as measure. ROE for the firms included in the sample were captured from rankings of America Economia "Las 500 mayores empresas de América Economia", in the period 2005-2011. ROE is a financial indicator of performance that shows the return for the shareholders of the firms and is commonly used in the literature (Dau, 2011). ROE is the amount of net income returned as a percentage of shareholders equity, it measures a corporation's profitability by revealing how much profit a company generates with the money shareholders have invested 
(Blaine, 1993; Glaum \& Oesterle, 2007). This indicator is expressed as a percentage and calculated as:

$$
\text { ROE = Net Income/ Shareholder's Equity }
$$

The analytic method applied to understand the relationship between variables was Linear Regression Analysis. The analyses were conducted using the SPSS 19 software.

\section{Results}

Table 1 shows reports the result of the descriptive statistics:

Table 1. Descriptive statistics

\begin{tabular}{lccccc}
\hline & N & Minimum & Maximum & Media & Tip. Dev. \\
\hline TPROP & 29 & 1.00 & 3.00 & 2.0345 & .49877 \\
ROE2005 & 29 & 3.15 & 79.45 & 26.4976 & 16.86832 \\
ROE2006 & 29 & -79.80 & 158.30 & 27.8966 & 38.13404 \\
ROE2007 & 29 & -51.40 & 105.10 & 26.0517 & 28.04237 \\
ROE2008 & 29 & -134.20 & 78.50 & 16.5414 & 41.77931 \\
ROE2009 & 29 & .70 & 78.30 & 23.1621 & 19.20349 \\
ROE2010 & 29 & -8.50 & 57.00 & 22.1241 & 15.72745 \\
ROE2011 & 29 & -11.00 & 77.10 & 22.2621 & 21.50062 \\
N valid & 29 & & & & \\
\hline
\end{tabular}

The media of ROE between 2005 and 2011 was 23. 35. These results show that the firms included in the study returns an average of 23.35 of revenues to their shareholders. It is important to point out that the standard deviation is unstable during the period. For instance, the standard deviation in 2010 is 15.72 and in 2008 is 41.77. It means 2010 the differences between the ROE's is bigger than the ROE's in 2008.

The table 2 below reports the result of the regression analysis for the sample:

Table 2. Regression model

\begin{tabular}{cccccccc}
\hline & $\begin{array}{c}\text { TPROP Vs. } \\
\text { ROE 2005 }\end{array}$ & $\begin{array}{c}\text { TPROP Vs. } \\
\text { ROE 2006 }\end{array}$ & $\begin{array}{c}\text { TPROP Vs. } \\
\text { ROE 2007 }\end{array}$ & $\begin{array}{c}\text { TPROP Vs. } \\
\text { ROE 2008 }\end{array}$ & $\begin{array}{c}\text { TPROP Vs. } \\
\text { ROE 2009 }\end{array}$ & $\begin{array}{c}\text { TPROP Vs. } \\
\text { ROE 2010 }\end{array}$ & $\begin{array}{c}\text { TPROP Vs. } \\
\text { ROE 2011 }\end{array}$ \\
\hline R & $.213^{\mathrm{a}}$ & $.234^{\mathrm{a}}$ & $.149^{\mathrm{a}}$ & $.274^{\mathrm{a}}$ & $.348^{\mathrm{a}}$ & $.042^{\mathrm{a}}$ & $.138^{\mathrm{a}}$ \\
$\mathrm{R} 2$ & .045 & .055 & .022 & .075 & .121 & .002 & .019 \\
F & 1.278 & 1.558 & .613 & 2.194 & 3.723 & .047 & .527 \\
Sig. & .268 & .223 & .440 & .150 & .064 & .831 & .474 \\
\hline
\end{tabular}

The results shown in Table 3 do not support the hypothesis. First, the results in all the period of study does not provide consistent support for the notion that "type of ownership" is related with the "financial performance" of firms that operates in Latin America. Second, the results of the regression analysis also show that practically the "type of ownership" is not factor that affects the financial performance. The results shows below are not according with other studies that reflect a positive influence of the "type of ownership" in the financial performance (Bozec, Breton \& Cote, 2002; Mazzolini, 1980). In addition it is important to point out that this study is one of the first carried out using a sample of Latin America firms.

Besides, the analyses of the $\mathrm{F}$ values do no support the main hypothesis. However, the major significance is on 2009. It means that in this year the "type of ownership" affects more than in other years the financial performance but even so it does not relevant.

Finally, the results reflects that the political and economic policies carried out for the governments in Latin America mainly during 90's that unchained changes in the ownership of the firms did not significant in the financial performance. It suggests that the national and international expansion of some Latin America firms was 
occasioned by other factors, but not for the changes related with the ownership.

\section{Conclusions and Future Research}

The aim of this paper is test if the type of ownership (Foreign Private, Local Private and State) affects the financial performance of firms in Latin America. The results suggest that the type of ownership is not a relevant factor in the financial performance. It supposes that the economic and political reforms during 90's were an important engine of development in all factors, however in the case of the firm's ownership it was not a relevant issue.

This paper contributes to the literature in three aspects. First, the study of the ownership in emerging regions is an important gap in the international business literature (Hitt, Tiyani, Miller \& Conelly, 2006; Pan \& Chao, 2010). Furthermore, the understanding of the effects of the ownership is useful in order to gain comprehensive knowledge about the ways in that the firms improve their general performance. Second, Latin America firms have been understudied in relation with firms from other regions around the world (Chang, 2010; Cuervo-Cazurra, 2010). Third, contributes to the debate of the benefits of the process of globalization around the world (Cuervo-Cazurra \& Dau, 2009; Rodrik, 2006) in concrete to move the discussion about the influence of the owners in the outcomes of the firms.

Besides the future direction of the research about the relationship type of ownership- financial performance will be to address another emerging market as Central Europa and Asia. Besides it is necessary analyze the influence of the public firms (that operates in stock market) in order to understand if this factor incise in the financial performance. Likewise an important topic is understand the role of the firms that operates in the stock exchanges (commonly known as public firms). Furthermore it is important to know the burden of family business in Latina America. In addition, it is valuable to study the type of ownership in separated way, it means by sector, country and size of the firm.

Moreover another important scope is including the "mixed firms" that are controlled for private and state owners at same time. Finally in order to verify results is important to carry out studies with a larger sample and in a larger period too. And study with these characteristics will be an important input to the literature about emerging markets.

\section{References}

Arocena, P., \& Oliveros, D. (2012). The efficiency of state-owned and privatized firms: Does ownership make a difference? International Journal of Production Economics, 140(1), 457-465. http://dx.doi.org/10.1016/j.ijpe.2012.06.029

Barnes, D., \& Hinton, C. M. (2012). Reconceptualising e-business performance measurement using an innovation adoption framework. International Journal of Productivity and Performance Management, 61(5), 502-517. http://dx.doi.org/10.1108/17410401211232948

Blaine, M. (1993). Profitability and competitiveness: lessons from Japanese and American firms in the 1980's. AJBS 1993 Best Papers Proceedings, Association of Japanese Business Studies, 1993.

Bozec, R., Breton, G., \& Cote, L. (2002). The performance of state owned enterprises revisited. Financial Accountability \& Management, 18(4), 383-407. http://dx.doi.org/10.1111/1468-0408.00158

Brudan, A. (2010). Rediscovering performance management: systems, learning and integration. Measuring Business Excellence, 14(1), 109-123. http://dx.doi.org/10.1108/13683041011027490

Casanova, L. (2010). Las multinacionales latinoamericanas en los albores de una oportunidad. Revista de Administracón de Empresas, Fundación Getulio Vargas, Brasil, 50(4), 439-445. http://dx.doi.org/10.1590/S0034-75902010000400008

Chang, J. (2011). The early and rapid internationalization of Asian emerging MNEs. Competitiveness Review: An International Business Journal Incorporating Journal of Global Competitiveness, 21(2), 171-187. http://dx.doi.org/10.1108/10595421111117452

Contractor, F. J., Kumar, V., \& Kundu, S. K. (2007). Nature of the relationship between international expansion and performance: The case of emerging market firms. Journal of World Business, 42(4), 401-417. http://dx.doi.org/10.1016/j.jwb.2007.06.003

Correa, R. (2002). Reformas estructurales y crecimiento en América Latina: un análisis de sensibilidad. Revista de la CEPAL. $\quad 76, \quad 89-107 . \quad$ Retrieved from http://www.eclac.cl/publicaciones/xml/5/19335/lcg2175e_Correa.pdf 
Cuervo-Cazurra, A. (2010). Multilatinas. Universia Business Review, 25, 14-33. Retrieved from http://ubr.universia.net/pdfs_web/25010-01.pdf

Cuervo-Cazurra, A., Inkpen, A., Mussachio, A., \& Ramaswamy, K. (2014). Goverments as owners: State-owned multinationals companies. Journal of International Business Studies, 1-24. Retrieved from http://www.palgrave-journals.com/jibs/cfp_global_state_own_si.html

Cuervo-Cazurra, A., \& Dau, L. A. (2009). Promarket reforms and firm profitability in developing countries. Academy of Management Journal, 52(6), 1348-1368. http://dx.doi.org/10.5465/AMJ.2009.47085192

D'souza, J., \& Megginson, W. L. (1999). The financial and operating performance of privatized firms during the 1990s'. Journal of Finance, LIV(4), 1397-438. http://dx.doi.org/10.1111/0022-1082.00150

Dau, L. A. (2011). Reforms, multinationalization, and profitability. Academy of Management Annual Meeting Proceedings (pp. 1-6). http://dx.doi.org/10.5465/AMBPP.2011.65870646

Dewenter, K. L., \& Malatesta, P. H. (2001). State-owned and privately-owned firms: An empirical analysis of profitability, leverage, and labor intensity. American Economic Review, 91(1), 320-34. http://dx.doi.org/10.1257/aer.91.1.320

Djankov, S., \& Murrell, P. (2002). Enterprise restructuring in transition: A quantitative survey. Journal of Economic Literature, 40, 739-792. http://dx.doi.org/10.1257/jel.40.3.739

Economic Comission for Latin America and Caribbean. (2012). Foreign Direct Investment in Latin America and and Caribbean.

Eskil, G., Grunfeld, L. A., \& Benito, G. R. G. (2008). The performance differential between private and state owned enterprises: The roles of ownership, management and market structure. Journal of Management Studies, 45(7), 0022-2380.

Filatotchev, I., Wright, M., Buck, T., \& Zhukov, V. (1999). Corporate entrepreneurs and privatized firms in Russia, Ukraine, and Belarus. Journal of Comparative Economics, 14, 475-492.

Glaum, M., \& Oesterle, M. J. (2007). 40 years of research on internationalization and firm performance: More questions than answers? Journal Management International Review, 47(3), 307-317.

González-Benito, J., \& Suarez-González, I. (2010). A study of the role played by manufacturing strategic objectives and capabilities in understanding the relationship between Porter's generic strategies and business performance. British Journal of Management, 21, 1027-1043. http://dx.doi.org/10.1111/j.1467-8551.2008.00626.x

Grant, R. M. (1987). Multinationality and performance among British manufacturing companies. Journal of International Business Studies, 18(1), 79-89. http://dx.doi.org/10.1057/palgrave.jibs.8490413

Haar, J. (1989). A comparative analysis of the profitability performance of the largest US, European and Japanese multinationals enterprises. Management International Review, 29(3), 5-19. Retrieved from http://www.jstor.org/discover/10.2307/40227933?uid=2134\&uid=2\&uid=70\&uid=4\&sid=21104567880393

Hitt, M. A., Hoskisson, R. E., \& Kim, H. (1997). International diversification: effects on innovation and firm performance in product-diversified firms. Academy of Management Journal, 40(4), 767-798. http://dx.doi.org/10.2307/256948

Hitt, M. A., Tihanyi, L., Miller, T., \& Conelly, B. (2006). International diversification: antecedents, outcomes, and moderators. Journal of Management, 32, 831-867. http://dx.doi.org/10.1177/0149206306293575

Kariv, D., Menzies, T. V., Brenner, G. A., \& Fillion, L. J. (2009). Transnational networking and business performance: Ethnic entrepreneurs in Canada. Entrepreneurship \& Regional Development, 21(3), 239-264. http://dx.doi.org/10.1080/08985620802261641

Knutsen, C. H., Rygh, A., \& Hyeem, H. (2011). Does state ownership matter? Institutions' effect on foreign direct investment revisited. Business and Politics, 13(1), 1-31. http://dx.doi.org/10.2202/1469-3569.1314

Le, T., \& Chizema, A. (2011). State ownership and firm performance: Evidence from the Chinese listed firms. Organizations and Markets in Emerging Economies, 2(4), 72-90.

Lebas, M. J. (1995). Performance measurement and performance management, International Journal of Production Economics, 41(1-3), 23-35. http://dx.doi.org/10.1016/0925-5273(95)00081-X

López-Morales, J. S., Wise-Lozano, J. A., \& Vargas-Hernandez, J. G. (2014). Emerging multinationals: Multilatinas. International Journal of Business and Social Research, 4(4), 150-159. Retrieved from 
http://thejournalofbusiness.org/index.php/site/article/view/351/381

Marr, B., \& Schiuma, G. (2003). Business performance measurement - past, present \& future. Management Decision, 41(8), 680-687. http://dx.doi.org/10.1108/00251740310496198

Mazzolini, R. (1980). Are state owned enterprises unfair competition? California Management Review. 20-28. http://dx.doi.org/10.2307/41164913

Megginson, W. L., \& Netter, J. F. (2001). From state to market: a survey of empirical studies on privatization. Journal of Economic Literature, 39(2), 321-389. http://dx.doi.org/10.1257/jel.39.2.321

Megginson, W. L., Nash, R. C., \& Van Randenborgh, M. (1994). The financial and operating performance of newly privatized firms: An international empirical analysis. The Journal of Finance, 49, 403-452. http://dx.doi.org/10.1111/j.1540-6261.1994.tb05147.x

Neely, A., Adams, C., \& Kennerley, M. (2002). The performance prism: the scorecard for measuring and managing business success. Hemel Hempstead: Financial Times-Prentice Hall.

Pan, W. H., \& Chao, Y. S. (2010). The joint effects of geographical diversification to MNE's performance through performance through China Investment. The Journal of Global Business, 6(1). Retrieved from http://www.jgbm.org/page/7\%20Yuang-Shiang\%20Chao\%20.pdf

Peng, M. W., Tan, J., \& Tong, T. W. (2004). Ownership Types and Strategic Groups in an Emerging Economy. Journal of Management Sciences, 1105-1129.

Reeves, E., \& Ryan, J. (1998). A benchmark analysis of the performance of state- owned enterprises in Ireland. International Journal of Public Administration, 21, 1577-602. http://dx.doi.org/10.1080/01900699808525361

Rodrik, D. (2006). Goodbye Washington Consensus, Hello Washington Confusion? A Review of the World Bank's Economic Growth in the 1990s: Learning from a Decade of Reform. Journal of Economic Literature, XLIV(December 2006), 973-987. http://dx.doi.org/10.1257/jel.44.4.973

Sandvik, I. L., \& Sandvik, K. (2003). The impact of market orientation on product innovativeness and business performance. International Journal of Research in Marketing, 20(4), 255-376. http://dx.doi.org/10.1016/j.ijresmar.2003.02.002

Taticchi, P., Balachandran, K., \& Tonelli, F. (2012). Performance measurement and management systems: state of the art, guidelines for design and challenges. Measuring Business Excellence, 16(2), 41-54. http://dx.doi.org/10.1108/13683041211230311

Thomas, D. E., \& Eden, L. (2004). What is the shape of the multinationality-performance relationship? The Multinational Business Review, 12(1), 89-110. Retrieved from http://www.voxprof.com/eden/Publications/eden-thomas-shape-mne-peformance-rel.pdf

Vernon, R. (1971). Sovereignty at Bay: The Multinational Spread of US Enterprises. Basic Books: New York.

Vij, S., \& Bedi, H. S. (2012). Relationship between Entrepreneurial Orientation and Business Performance: A review and Business Performance: A Review of Literature. The IUP Journal of Business Strategy, IX(3), 17-31. Retrieved from http://www.lib.yuntech.edu.tw/ exam/exam_new/102/dmb.pdf

Wright, M., Buck, T., \& Filatotchev, I. (2002). Post-privatization effects of management and employee buyouts. Annals of Public and Cooperative Economics, 73, 303-52. http://dx.doi.org/10.1111/1467-8292.00195

Yarrow, G. (1986). Privatization in theory and practice. Economic Policy, 1(2), 323-377. http://dx.doi.org/10.2307/1344560

\section{Copyrights}

Copyright for this article is retained by the author(s), with first publication rights granted to the journal.

This is an open-access article distributed under the terms and conditions of the Creative Commons Attribution license (http://creativecommons.org/licenses/by/3.0/). 